\title{
Reduced Tissue Levels of Noradrenaline Are Associated with Behavioral Phenotypes of the TgCRND8 Mouse Model of Alzheimer's Disease
}

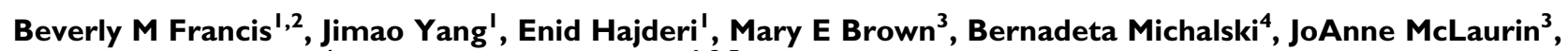 \\ Margaret Fahnestock ${ }^{4}$ and Howard TJ Mount, ${ }^{*, 1,2,5}$ \\ 'Tanz Centre for Research in Neurodegenerative Diseases, University of Toronto, Toronto, ON, Canada; ${ }^{2}$ Department of Physiology, University of \\ Toronto, Toronto, ON, Canada; ${ }^{3}$ Department of Laboratory Medicine and Pathobiology, University of Toronto, Toronto, ON, Canada; \\ ${ }^{4}$ Department of Psychiatry and Behavioral Neurosciences, McMaster University, Hamilton, ON, Canada; ${ }^{5}$ Division of Neurology, Department of \\ Medicine, University of Toronto, Toronto, ON, Canada
}

Noradrenergic cell loss is well documented in Alzheimer's disease (AD). We have measured the tissue levels of catecholamines in an amyloid precursor protein-transgenic 'TgCRND8' mouse model of AD and found reductions in noradrenaline (NA) within hippocampus, temporoparietal and frontal cortices, and cerebellum. An age-related increase in cortical NA levels was observed in non-Tg controls, but not in TgCRND8 mice. In contrast, NA levels declined with aging in the TgCRND8 hippocampus. Dopamine levels were unaffected. Reductions in the tissue content of NA were found to coincide with altered expression of brain-derived neurotrophic factor (BDNF) mRNA and to precede the onset of object memory impairment and behavioral despair. To test whether these phenotypes might be associated with diminished NA, we treated mice with dexefaroxan, an antagonist of presynaptic inhibitory $\alpha_{2}$-adrenoceptors on noradrenergic and cholinergic terminals. Mice 12 weeks of age were infused systemically for 28 days with dexefaroxan or rivastigmine, a cholinesterase inhibitor. Both dexefaroxan and rivastigmine improved TgCRND8 behavioral phenotypes and increased BDNF mRNA expression without affecting amyloid- $\beta$ peptide levels. Our results highlight the importance of noradrenergic depletion in AD-like phenotypes of TgCRND8 mice.

Neuropsychopharmacology (2012) 37, 1934-1944; doi:10.1038/npp.2012.40; published online II April 2012

Keywords: noradrenaline; dexefaroxan; memory; BDNF; rivastigmine; amyloid

\section{INTRODUCTION}

The temporal neocortex, entorhinal cortex, and hippocampus are the earliest sites of amyloid- $\beta(\mathrm{A} \beta)$ deposition and the first to become functionally disrupted in the Alzheimer's disease (AD) brain (Braak and Braak, 1991; DeToledoMorrell et al, 1997; Thal et al, 2000, 2002; Braak and Del Tredici, 2004; Stoub et al, 2010). Subcortical neurons that project to these areas are especially vulnerable to $\mathrm{A} \beta$ toxicity (Gonzalo-Ruiz et al, 2003). Degeneration of basal forebrain cholinergic neurons in AD was initially described in 1976 (Davies and Maloney, 1976) and the corresponding role of these neurons in the pathology and behavioral presentation of the disease has been well documented

* Correspondence: Dr HTJ Mount, Tanz Centre for Research in Neurodegenerative Diseases, University of Toronto, 6 Queen's Park Crescent West, Toronto, ON M5S 3H2, Canada, Tel: + I 416978 1874, Fax: + | 416978 1878,

E-mail: howard.mount@utoronto.ca

Received 25 November 2011; revised 15 February 2012; accepted 2 March 2012
(Coyle et al, 1983; Francis et al, 1999). Less well appreciated has been the profound loss of noradrenergic innervation from the locus coeruleus (Zarow et al, 2003). Forno (1966) was the first to report severely reduced cell counts in the locus coeruleus of AD patients. Subsequent studies revealed $>60 \%$ loss of noradrenergic cells (Mann et al, 1982; Bondareff et al, 1982; German et al, 1992) and depleted tissue levels of noradrenaline (NA) in cortical and limbic terminal fields (Adolfsson et al, 1979; Palmer et al, 1987a, b; Matthews et al, 2002). The extent of noradrenergic degeneration was found to correlate with the tissue load of amyloid plaques and neurofibrillary tangles, as well as with the severity of dementia (Bondareff et al, 1987; Grudzien et al, 2007).

The locus coeruleus projects widely in the brain and is the sole source of NA in the neocortex and hippocampus (Foote et al, 1983). The loss of cortical noradrenergic innervation and its influence on basalocortical cholinergic neurons may contribute to behavioral symptoms of $\mathrm{AD}$ including depression and memory impairment (reviewed by Marien et al, 2004). In rats treated with scopolamine to block 
cholinergic function, enhancing NA release facilitated memory retention (Chopin et al, 2002), whereas ablating the locus coeruleus exacerbated working memory deficits (Ohno et al, 1997). Non-selectively targeting the locus coeruleus of human amyloid precursor protein (APP) mice with the neurotoxin $\mathrm{N}$-(2-chloroethyl)- $\mathrm{N}$-ethyl-2-bromobenzylamine (DSP-4) potentiated amyloid pathology, glial inflammation, neuronal loss, and cognitive impairment (Heneka et al, 2006; Kalinin et al, 2007; JardanhaziKurutz et al, 2010, 2011). Collectively, these data point to a likely role for noradrenergic dysfunction in the pathogenesis of $\mathrm{AD}$ and an interaction with the basal forebrain cholinergic system.

We investigated if and when noradrenergic deficits might spontaneously occur in the TgCRND8 (Janus et al, 2000; Chishti et al, 2001) amyloid precursor protein-transgenic (APP-Tg) mouse. These mice exhibit deficits in memory and brain-derived neurotrophic factor (BDNF) mRNA as early as 2 months (Francis et al, 2012), significant plaque loads within hippocampus and cortex by 3 months (Chishti et al, 2001) and cholinergic dysfunction by 7 months of age (Bellucci et al, 2006). We now report that reductions in tissue NA precede the appearance of plaques and cholinergic dysfunction and strongly contribute to behavioral phenotypes and decreased BDNF expression.

\section{MATERIALS AND METHODS}

\section{Transgenic Mice}

TgCRND8 mice express a double mutant (Swedish: KM670/ $671 \mathrm{NL}$ plus Indiana: V717F) human $\mathrm{APP}_{695}$ transgene under control of the pan-neuronal Syrian hamster prion gene promoter. Transgenic mice were maintained on a hybrid C57BL/6/C3H background and were backcrossed with C57BL/6 wild-type mice. Mice were housed in groups of two to four on a 12-h light-dark cycle. Food and water were available ad libitum. All tests were in accordance with the Canadian Council on Animal Care guidelines and were approved by the Animal Care Committee at the University of Toronto.

\section{Brain Fixation and Microdissection}

TgCRND8 and non-Tg littermates ( $n \geqslant 8$ per group) were killed at 4-5, 7-9, or 40-50 weeks of age with a brief (0.8$1.2 \mathrm{~s})$ head-focused pulse of microwave radiation $(8 \mathrm{~kW}$, $60 \mathrm{~Hz}, 56 \mathrm{Amp}$ ) delivered by a $10-\mathrm{kW}$ Muromachi rodent brain fixation system (model TMW-4012C, Muromachi Kikai, Tokyo, Japan). This procedure rapidly heat-inactivates enzymes, thereby preserving levels of labile biogenic amines at concentrations that existed ante-mortem (Moroji et al, 1978; Wood and Altar, 1988; Mount et al, 2004). The microwaved frontal, parietal and occipital cortices, anterior and posterior brainstem, hippocampus, ventral midbrain, striatum, and cerebellum were dissected on ice (Supplementary Figure S1) and stored at $-80{ }^{\circ} \mathrm{C}$ until analysis.

\section{Tissue Catecholamines}

Levels of dopamine (DA), dihydrophenylacetic acid (DOPAC), homovanillic acid (HVA), 3-methoxytyramine
(3-MT), and NA were measured by HPLC, as previously described (Mount et al, 2004). Regional cooked tissues were homogenized in $1 \mathrm{ml}$ ice-cold $0.1 \mathrm{~N}$ perchloric acid. Homogenates were centrifuged at $10000 \mathrm{~g}$ for $20 \mathrm{~min}$ at $4{ }^{\circ} \mathrm{C}$. The supernatants were filtered through $0.2 \mu \mathrm{m}$ porosity membrane (PALL Corporation, Ann Arbor, MI, USA) and stored in aliquots of $50 \mu \mathrm{l}$ at $-80{ }^{\circ} \mathrm{C}$. Equipment for isocratic reverse-phase chromatographic measurements was from Dionex and was operated with the Chromeleon Chromatography Data Management System, version 6.8 (DIONEX, Sunnyvale, CA, USA). Chemicals for standards and mobile phase solutions were purchased from Sigma-Aldrich (St Louis, MO, USA). The chromatographic conditions consisted of a C18 reverse-phase column (Acclaim 120, $150 \times 4.0 \mathrm{~mm}^{2}, 5 \mu \mathrm{m}$ particle size) maintained at $30{ }^{\circ} \mathrm{C}$ (UltiMate 3000 Thermostatted Column Compartment). The mobile phase was sodium acetate $(100 \mathrm{mM})$, tetrasodium EDTA $(0.125 \mathrm{mM})$, 1-octane sulfonic acid $(432 \mathrm{mg} / \mathrm{l})$, and $5 \%$ methanol $(\mathrm{pH} 3.6)$ and was delivered at a flow rate of $0.75 \mathrm{ml} / \mathrm{min}$ with an UltiMate 3000 pump. In all, $25 \mu \mathrm{l}$ of each sample and $20 \mu$ of each standard were injected automatically using a refrigerated UltiMate 3000 autosampler. The electrochemical detector (ESA Coulochem III, 5011A analytical cell plus 5020 guard cell) was operated at a working electrode potential of $-400 \mathrm{mV}$.

\section{Tail Suspension Test}

Gender balanced groups of 4-, 8-, and 27-week-old TgCRND8 and non-Tg mice ( $n \geqslant 8$ per group) were tested with the tail suspension test. Mice were suspended for $6 \mathrm{~min}$ by affixing masking tape to the end of their tails and attaching the tape to a clamp on a ring stand. Latency to immobility and duration of immobility were scored with ODlog event recording software (Macropod Software, Armidale, Australia). To test how altered tissue NA levels affect measured end points, separate groups of experimentally naive 30 -week-old mice $(n \geqslant 6)$ were administered the NA uptake inhibitor, desipramine $(16 \mathrm{mg} / \mathrm{kg}$, i.p.; Sigma-Aldrich Canada, Oakville, Canada), or saline $30 \mathrm{~min}$ before testing.

\section{Drug Treatments, Behavioral Testing, and Tissue Processing}

We investigated the effects of 28-day infusion of dexefaroxan $(1.9 \mathrm{mg} / \mathrm{kg} /$ day $)$, rivastigmine $(0.48 \mathrm{mg} / \mathrm{kg} /$ day $)$, or saline on TgCRND8 behavioral phenotypes. Dexefaroxan hydrochloride (2-[2-(2-ethyl-2,3-dihydrobenzofuranyl)]-2-imidazoline) was synthesized at Pierre Fabre Medicament (Castres, France) and rivastigmine tartrate (Exelon) was obtained from Novartis Pharma AG (Basel, Switzerland). Drugs were administered via Alzet (DURECT Corporation, Cupertino, CA, USA) osmotic mini-pumps (model 1002) implanted subcutaneously in the mid-scapulary region. In all, 120 mice (6 gender balanced groups of 20 mice) were fitted with pumps at 12 weeks of age and were treated chronically for 28 days. Pumps delivered $100 \mu$ l of solution at a rate of $0.25 \mu \mathrm{l} / \mathrm{h}$ for 2 weeks. Primed pumps were soaked overnight in saline at $37^{\circ} \mathrm{C}$ before implantation. During surgery, mice were anesthetized via isoflurane inhalation. A second surgery was performed on treatment day 14 to replace the depleted pump. Habituation for object recognition testing 
began the day after the second pump was implanted (third week of chronic treatment). Habituation involved handling mice and exposing them to an empty home cage for $15 \mathrm{~min}$ per day over 3 days. This regimen ensured that experimentally naive mice received 2 weeks of continuous drug treatment before assessment and were sufficiently habituated for measures of behavior. The object recognition test was conducted on treatment day 19, as described previously (Francis et al, 2012). Each mouse was exposed for $10 \mathrm{~min}$ to a LEGO construct (LEGO Group, Billund, Denmark) and a Hot Wheels car (Mattel, El Segundo, CA, USA). Three hours later, mice were re-exposed for $5 \mathrm{~min}$ to 1 object from the original test pair and to a novel object. The memory index (MI) was calculated as $\mathrm{MI}=\left(t_{\mathrm{n}}-t_{\mathrm{f}}\right) /\left(t_{\mathrm{n}}+t_{\mathrm{f}}\right)$, wherein ' $t_{\mathrm{n}}$ ' represents time exploring a novel object and ' $t_{\mathrm{f}}$ ' the duration of familiar object exploration. On the following day, we assessed behavioral despair in the tail suspension task. At the end of the drug treatment, 16-week-old mice were anesthetized with an overdose of sodium pentobarbital $(60 \mathrm{mg} / \mathrm{kg})$ and perfused transcardially with ice-cold phosphate-buffered saline (0.1 M PBS, $\mathrm{pH} 7.4$ ). The hippocampus and cortex were dissected, snap frozen, and stored at $-80^{\circ} \mathrm{C}$ for $\mathrm{A} \beta$ analyses and BDNF mRNA measurements.

\section{A $\beta$ Immunoassays}

The concentration of aggregated $\mathrm{A} \beta$ in the cortex of drugtreated mice ( $n=7$ per group) was measured using the Amorfix $\mathrm{A}^{4}$ assay (Amorfix, Mississauga, Canada) as previously described (Tanghe et al, 2010). Tissues were homogenized $(10 \% \mathrm{w} / \mathrm{v})$ in $2 \%(\mathrm{v} / \mathrm{v})$ nonyl phenoxylpolyethoxylethanol (NP-40) in PBS containing $1 \mathrm{mM}$ phenylmethylsulfonyl fluoride and protease inhibitor cocktail (Complete Mini, Roche, Quebec, Canada). Homogenates were centrifuged at $845 \mathrm{~g}$ for $30 \mathrm{~s}$ and the supernatant was aliquotted. One aliquot was further diluted to a $1 / 10000$ concentration to provide a signal within the linear range of the immunoassay. Using the $\mathrm{A}^{4}$ proprietary enrichment protocol (Amorfix, Mississauga, Canada), only aggregated species of $\mathrm{A} \beta$ were isolated from the sample. The eluate was then disaggregated to quantify $\mathrm{A} \beta$ in its monomeric form using the Amorfix dual-bead based immunoassay using europium-fluorescent beads coupled to the $\mathrm{N}$-terminal 4 G10 antibody and magnetic beads coupled to $1 F 8$ and $2 \mathrm{H} 12 C$-terminal antibodies recognizing $\mathrm{A} \beta_{40}$ and $\mathrm{A} \beta_{42}$, respectively. The europium-fluorescent intensity was measured using time-resolved fluorescence on triplicate samples and is directly proportional to the concentration of $\mathrm{A} \beta$ in the tissue. To measure levels of monomeric $\mathrm{A} \beta$ in the cortical samples, another aliquot of the homogenate was diluted (1/500) and loaded directly into the Amorfix immunoassay, without the $\mathrm{A}^{4}$ enrichment or disaggregation steps. Separate immunoassays were performed to detect monomeric $\mathrm{A} \beta_{40}$ and $\mathrm{A} \beta_{42}$. The detection limit of the immunoassay was $50 \mathrm{fg} /$ well.

\section{Western Blotting}

Aliquots of cortical tissue homogenates used in the $\mathrm{A} \beta$ immunoassays were spun at 3000 r.p.m. for $10 \mathrm{~min}$ at $4{ }^{\circ} \mathrm{C}$, and the protein concentration of supernatants were determined. In all, $20 \mu \mathrm{g}$ of protein was prepared in sample buffer, boiled for $5 \mathrm{~min}$, separated by gel electrophoresis on 10-20\% Tricine gels (Invitrogen, Burlington, Canada), and transferred to nitrocellulose membranes. Membranes were boiled in Tris-buffered saline (TBS), blocked for an hour in $8 \%$ non-fat milk powder in TBS-Tween $(0.2 \%)$ at room temperature, and incubated overnight at $4{ }^{\circ} \mathrm{C}$ with $\mathrm{A} \beta_{1-16}$ monoclonal antibody 6E10 ( $1: 1000$; SIG-39320, Covance, Montreal, Canada). After 1 -h incubation with goat antimouse horseradish-peroxidase-conjugated secondary antibody $(1: 5000$, Thermo Scientific Pierce, Rockford, IL, USA), membranes were developed using enhanced chemiluminescence (Amersham ECL Western blotting analysis system, GE Healthcare, Quebec, Canada) and exposed to film. Blots were stripped and reprobed with anti-glyceraldehyde-3-phosphate dehydrogenase (GAPDH) antibody (1:7500; Meridian Life Sciences, Brockville, Canada). Densitometry was quantified for three separate blots with Image J $1.44 \mathrm{~V}$ software (National Institutes of Health). Data were normalized to the corresponding expression level of GAPDH in each sample.

\section{Measurement of BDNF mRNA}

Ribonucleic acid (RNA) isolation, reverse transcription, and absolute quantitative real-time polymerase chain reaction (RT-PCR) for measurement of BDNF mRNA in hippocampal tissues from 16-week-old drug-treated mice $(n \geqslant 6$ per group) were performed as previously described, with minor changes (Peng et al, 2009). Hippocampal BDNF mRNA was also measured in an older cohort (45-50 weeks old) of mice chronically infused with dexefaroxan or rivastigmine for 4 weeks. RNA extraction was performed using Trizol (Invitrogen) and RNeasy spin columns (Qiagen, Toronto, Canada). DNase treatment was done on columns as per the Qiagen protocol. RNA integrity was verified by agarose gel electrophoresis. For reverse transcription, Invitrogen's protocol and reagents for Superscript III were used. The forward and reverse PCR primers used for mouse BDNF mRNA were 5' GCG GCA GAT AAA AAG ACT GC and 5' CTT ATG AAT CGC CAG CCA AT, product $248 \mathrm{bp}$. Results were normalized to $\beta$-actin mRNA. The forward and reverse primers used for $\beta$-actin mRNA were $5^{\prime}$ AGC CAT GTA CGT AGC CAT CC and $5^{\prime}$ CTC TCA GCT GTG GTG GTG AA, product $228 \mathrm{bp}$. Purified PCR products derived from use of these primers were used as standards for BDNF and $\beta$-actin. The following thermal profile was used for PCR: $2 \mathrm{~min}$ at $50{ }^{\circ} \mathrm{C}, 2 \mathrm{~min}$ at $95^{\circ} \mathrm{C}$ followed by 40 cycles of $95^{\circ} \mathrm{C}$ for $30 \mathrm{~s}$, $58{ }^{\circ} \mathrm{C}$ for $30 \mathrm{~s}$, and $72{ }^{\circ} \mathrm{C}$ for $45 \mathrm{~s}$. Unknowns, standard curve, and controls were run in triplicate using SYBR Green. Only experiments with an $R^{2}>0.995$ and PCR efficiency $>90 \%$ were used in the analysis. A dissociation curve verified that no secondary products had formed.

\section{Statistical Analysis}

Data were evaluated by unpaired Student's $t$-tests. Multiple comparisons were analyzed by a non-repeated measures two-way analysis of variance (ANOVA). When ANOVAs yielded significant main effects of genotype and/or treatment, pairwise comparisons were evaluated by Fisher's protected least significant difference (LSD) test. Differences were significant at $P<0.05$. 


\section{RESULTS}

TgCRND8 Mice Exhibit Early Reductions in NA Content Within Major Terminal Fields

Tissue levels of NA, DA, and their metabolites were measured across brain regions of 4-5, 7-9, and 40-50 weeks old TgCRND8 and non-Tg littermate mice and data were analyzed by the two-tailed Student's $t$-test for independent samples. We observed an early and reliable pattern of reduced NA in the frontal and temporoparietal cortices, hippocampus, and cerebellum (Figure 1). Neither DA nor its metabolites (DOPAC, HVA, 3-MT) were consistently altered (Supplementary Table S1). With aging, NA reductions in the TgCRND8 mice worsened in hippocampus, but remained stable in cortical regions. In contrast, aging control mice exhibited increased NA levels in the temporoparietal and frontal cortices. Levels of NA in the ventral mesencephalon, striatum, and brainstem were unaffected, suggesting that rostral, cortically projecting noradrenergic cells of the locus coeruleus are the most severely disrupted in this mouse model of $\mathrm{AD}$.

\section{TgCRND8 Mice Display Behavioral Despair in the Tail Suspension Test}

To determine whether reductions in tissue NA content might be accompanied by development of a depressive phenotype, we tested 4-, 8-, and 27-week-old TgCRND8 and littermate control mice in the tail suspension test (Figure 2). Behavioral despair in this task is defined as an increase in immobility in response to inescapable stress (Steru et al, 1985). The hippocampus and frontal cortex are the neuroanatomical substrates of the stress-induced, depressive-like response in the tail suspension test (Galeotti and Ghelardini, 2011). Mice were considered immobile when they hung motionless with their limbs tucked against their bodies. At 4 weeks of age, TgCRND8 mice were indistinguishable from controls in their latency to immobility $(t(17)=1.49, P=0.156)$ as well as duration of immobility $(t(17)=0.08, P=0.936)$. At 8 weeks, TgCRND8 mice were quicker to become immobile $(t(18)=2.71, P=0.014)$ and by 27 weeks they exhibited both reduced latency to $(t(17)=3.30, \quad P=0.004)$ and increased duration of $(t(17)=2.31, P=0.033)$ immobility.
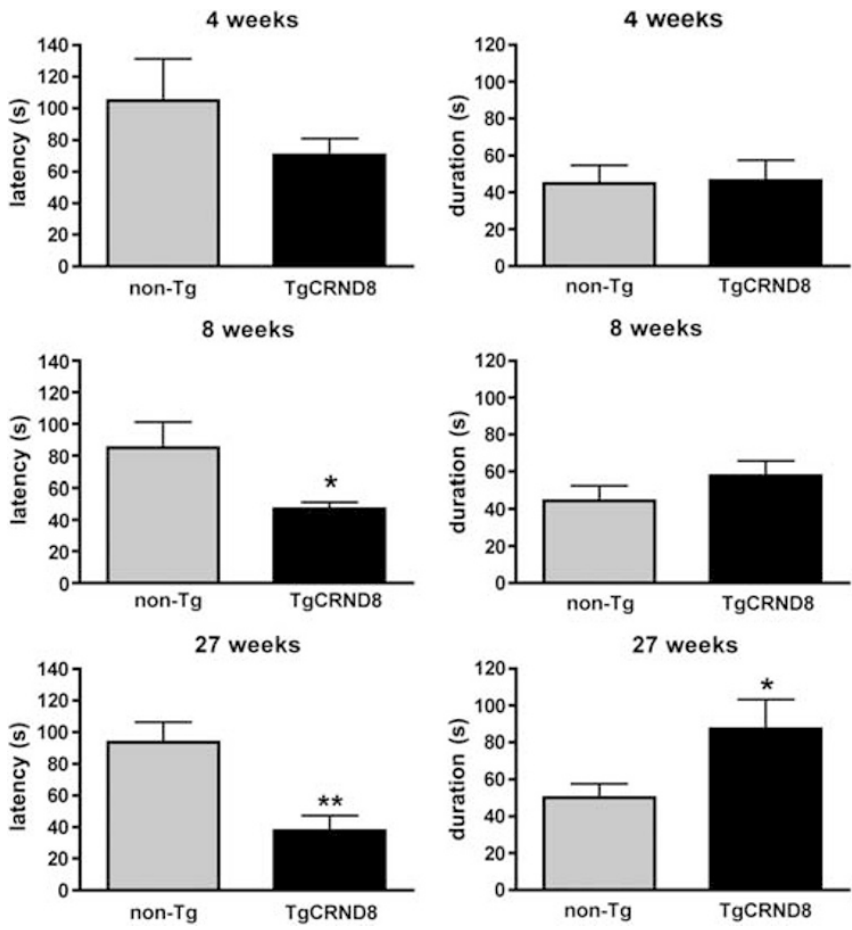

Figure 2 TgCRND8 mice exhibit pronounced behavioral despair in the tail suspension test. Latency to immobility (left panel) and duration of immobility (right panel) were measured in 4-, 8-, and 27-week-old mice that were suspended by their tails for $6 \mathrm{~min}$. At 8 weeks, TgCRND8 mice became immobile quickly. By 24 weeks, they also spent more of the test period immobile. Data are mean values \pm SEM of $n \geqslant 8$ mice per group. $* P \leqslant 0.05$, *** $P \leqslant 0.0$ I vs non-Tg animals by Student's unpaired $t$-test.
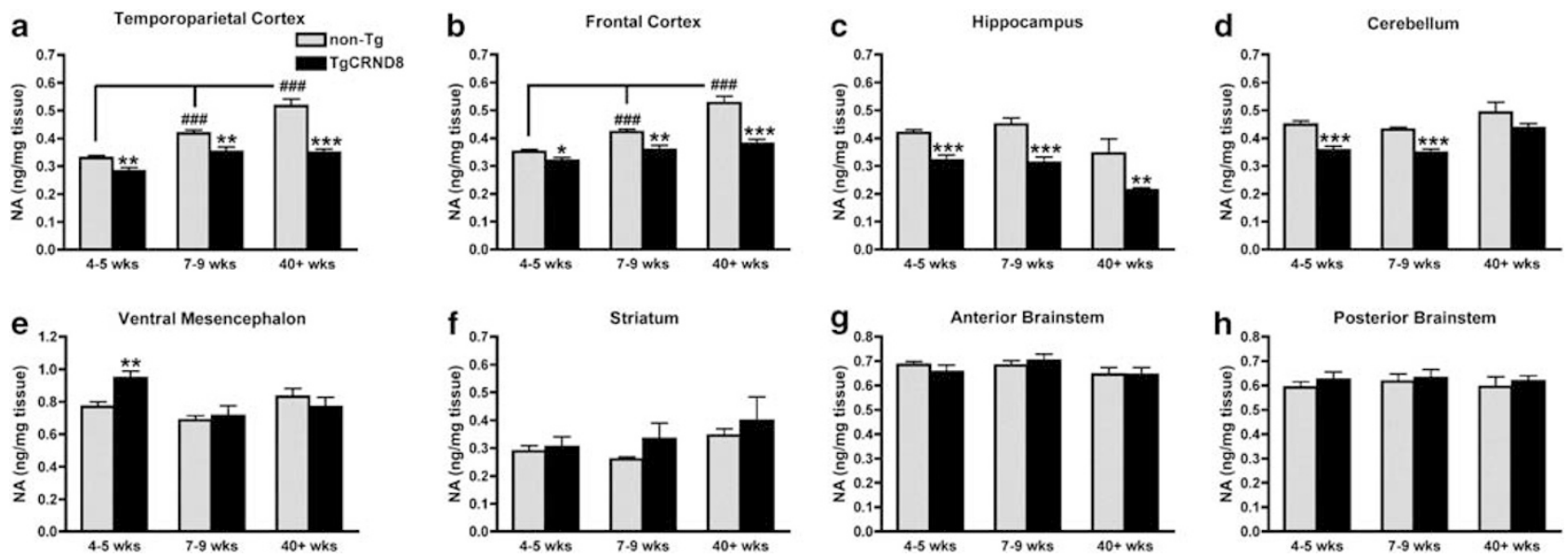

Figure I Tissue levels of noradrenaline (NA) are reduced in major terminal fields of the TgCRND8 brain. Reductions in tissue NA were observed in temporoparietal cortex (a), frontal cortex (b), hippocampus (c), and cerebellum (d). No reductions were observed within ventral mesencephalon (e), striatum ( $f$ ), or anterior $(\mathrm{g})$ and posterior brainstem $(\mathrm{h})$ regions. $* P<0.05, * * P<0.0 \mathrm{l}$, and $* * * P<0.00 \mathrm{I}$ vs non-Tg mice by two-way ANOVA followed by Fisher's protected LSD test. Non-Tg mice exhibited NA tissue levels in the temporoparietal and frontal cortices that increased with aging. ${ }^{\# \# \# ~} P \leqslant 0.00$ I vs 4 to 5 -week-old non-Tg mice by two-way ANOVA followed by Fisher's protected LSD test. Values are means of NA tissue content (ng/mg tissue) \pm SEM of $n \geqslant 8$ mice per group. 


\section{Desipramine Alleviates Behavioral Despair}

Desipramine, a NA reuptake inhibitor, has been shown to effectively reduce behavioral despair in C57BL/6 mice in the tail suspension test (Steru et al, 1985; Cryan et al, 2005). We found significant main effects of both genotype $\left(\mathrm{F}_{1,20}=26.30, P<0.001\right)$ and desipramine $\left(\mathrm{F}_{1,20}=41.55\right.$, $P<0.001)$ on duration of immobility. Although desipramine increased the latency to immobility in both TgCRND8 and non-Tg mice, we did not see a significant effect of genotype on latency scores (data not shown). The stress of i.p. injections may have influenced latency scores, as has been reported previously (Barfield et al, 2010). Thus, duration of immobility is deemed the most reliable readout of the tail suspension test (Cryan et al, 2005). Desipramine slightly reduced the duration of immobility (Figure 3 ) in non-Tg mice $(t(11)=2.23, P=0.048)$, but profoundly reduced immobility in TgCRND8 mice $(t(9)=5.97, P=0.0002)$, so as to render the response of these animals indistinguishable from that of saline-treated non-Tg mice $(t(10)=1.03$, $P=0.33)$. These results suggest that increasing synaptic NA has an anti-depressive effect in the tail suspension test.

\section{Dexefaroxan and Rivastigmine Reduce Object Memory Impairment and Behavioral Despair}

Twelve-week-old TgCRND8 mice and non-Tg littermates were treated with dexefaroxan, rivastigmine, or saline for 4 weeks and were subjected to object memory and tail suspension tests. The $12-16$ week window is a relevant timeframe for therapeutic assessment in TgCRND8 mice as robust spatial memory impairment develops by 12 weeks and plaque deposition is evident at 15 weeks of age (Chishti et al, 2001; Janus et al, 2000). Dexefaroxan enhances noradrenergic transmission by antagonizing inhibitory $\alpha_{2}$-adrenoceptors. The dose was adopted from a study in which daily injections of dexefaroxan were found to enhance olfactory bulb neurogenesis (Veyrac et al, 2005). Others have verified stable pharmacological activity of an

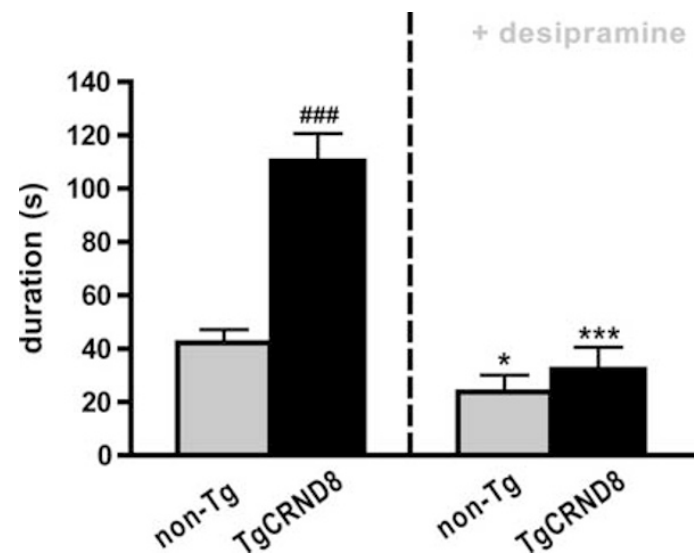

Figure 3 Desipramine reduces immobility in the tail suspension test. Thirty-week-old TgCRND8 and non-Tg mice received an injection of either desipramine or saline $30 \mathrm{~min}$ before the test. Desipramine reduced time mice spent immobile. Data are mean values \pm SEM of $n \geqslant 6$ mice per group. $* P \leqslant 0.05$, **** $P \leqslant 0.001$ vs saline-treated animals of matched

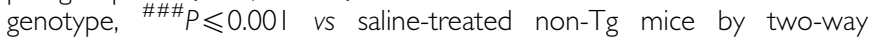
ANOVA followed by Fisher's protected LSD test. equivalent dexefaroxan dose delivered chronically in rats via mini-osmotic pumps (Chopin et al, 2002; Debeir et al, 2002; Rizk et al, 2006). Tolerance to a facilitatory effect of dexefaroxan on cognition was not observed even after chronic infusion for 25 days (Chopin et al, 2002). We compared the effects of dexefaroxan to those of rivastigmine, a clinical cholinesterase inhibitor used to treat memory deficits in $\mathrm{AD}$. The dose of rivastigmine administered in this study previously was found to improve spatial memory in APP23-Tg mice (Van Dam et al, 2005).

Regardless of genotype or drug treatment, mice spent an equivalent amount of time exploring objects during the acquisition trial (Figure $4 \mathrm{a}$ ). The set of objects used for this task was predetermined to ensure matched saliency and we did not observe group differences in object preference during the acquisition trial (data not shown). Object memory (Figure 4b) was calculated following a 3-h retention interval with a MI, where a score of 0 indicates no preference for the novel object. Both genotype $\left(\mathrm{F}_{1,50}=21.52, P<0.0001\right)$ and treatment $\left(\mathrm{F}_{2,50}=7.07, \quad P=0.002\right) \quad$ significantly influenced object memory. At 14 weeks of age, TgCRND8 mice were severely impaired on this test $(t(15)=9.13$, $P<0.001)$. A reversal of the memory deficit was observed
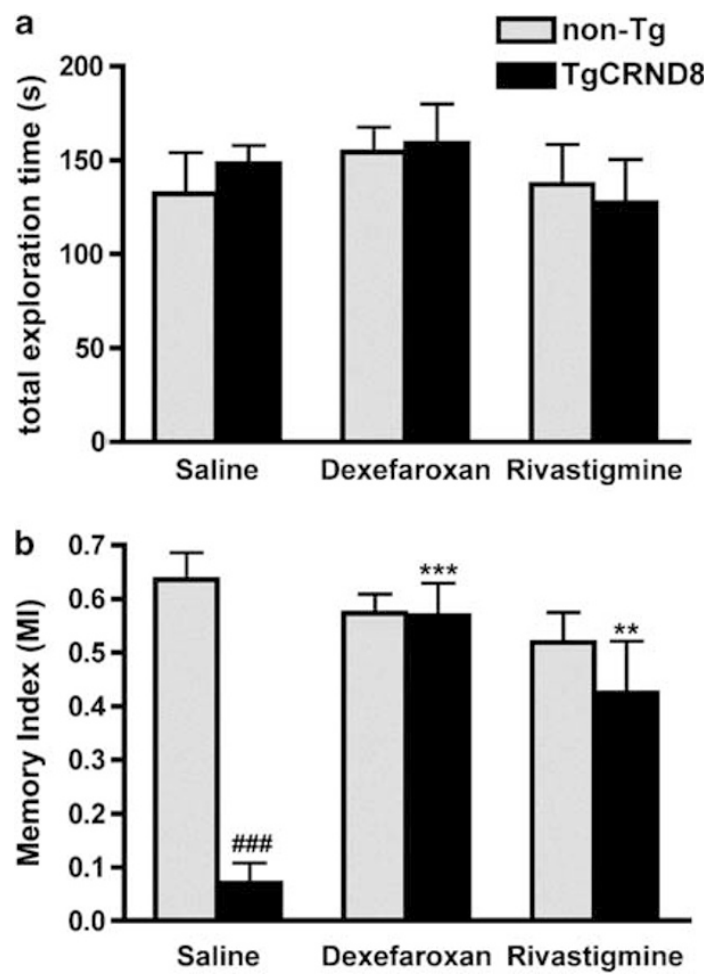

Figure 4 Dexefaroxan and rivastigmine affect memory, but not exploration of objects. On day 19 of treatment with dexefaroxan, rivastigmine or saline, I4-week-old TgCRND8 and littermate control mice were tested on the object recognition task. (a) Time spent exploring the objects during the initial exposure period are compared. (b) Three hours after this initial exposure, mice were re-exposed to an object from the original test pair and to a novel object. An object memory index was calculated as described in Materials and Methods. Both dexefaroxan and rivastigmine abolished object memory deficits of TgCRND8 mice. Results are mean values \pm SEM of $8-1$ I mice per group. *** $P \leqslant 0.01$, **** $P \leqslant 0.00$ I vs saline-treated controls, ${ }^{\# \# \#} P \leqslant 0.001$ vs non-Tg saline-treated mice by two-way ANOVA followed by Fisher's protected LSD test. 


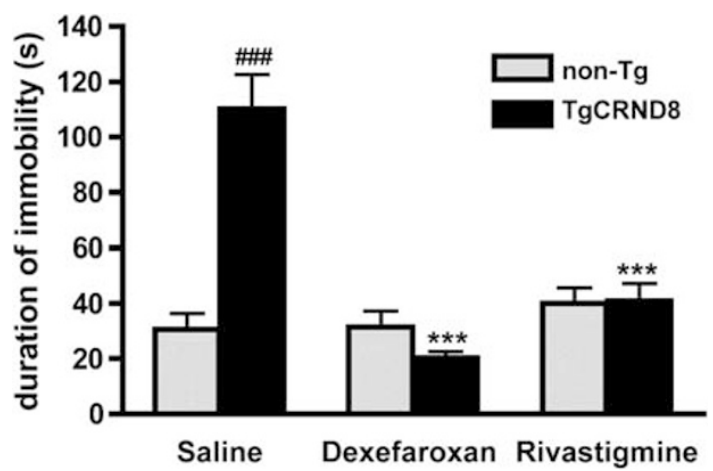

Figure 5 Dexefaroxan and rivastigmine reduce behavioral despair. One day after object recognition testing, 14- to 15-week-old TgCRND8 and littermate drug-treated mice were subjected to the tail suspension test. Saline-treated TgCRND8 mice exhibited behavioral despair, spending more of the test time immobile than did control animals. Dexefaroxan and rivastigmine reduced behavioral despair to levels observed in non-Tg mice. Data are mean values \pm SEM for $6-13$ mice per group. $* * * * \leqslant 0.001$ vs saline-treated controls, ${ }^{\# \# \# ~} P \leqslant 0.00$ I vs non-Tg saline-treated mice by twoway ANOVA followed by Fisher's protected LSD test.

in TgCRND8 mice chronically infused with either dexefaroxan $(t(18)=6.57, P<0.001)$ or rivastigmine $(t(15)=3.59$, $P=0.003)$. The performance of non-Tg mice in the object recognition test was not altered with dexefaroxan $(t(16)=1.04, \quad P=0.31) \quad$ or rivastigmine $(t(16)=1.51$, $P=0.15)$ treatment. On the 20th day of chronic infusion with either drug or saline, mice were tested on the tail suspension test (Figure 5). We found that both genotype $\left(\mathrm{F}_{1,54}=20.35, \quad P<0.0001\right)$ and treatment $\left(\mathrm{F}_{2,54}=24.80\right.$, $P<0.0001)$ significantly affected time mice spent immobile in this test. We found that 14- to 15-week-old TgCRND8 mice were behaviorally depressed, with longer durations of immobility than non-Tg controls $(t(14)=6.59, P<0.0001)$. Immobility of TgCRND8 mice was dramatically reduced with both dexefaroxan $(t(15)=9.45, P<0.0001)$ and rivastigmine $(t(12)=5.36, P=0.0002)$. The immobility of non-Tg mice was unaffected by either dexefaroxan $(t(19)=1.75, P=0.09)$ or rivastigmine $(t(16)=1.21, P=0.24)$, suggesting that a floor effect for immobility scores was achieved.

\section{Treatments Do Not Affect Amyloid Burden}

We investigated how dexefaroxan and rivastigmine might affect $\mathrm{A} \beta$ load in TgCRND8 mice. Levels of monomeric $\mathrm{A} \beta_{42}$ and $\mathrm{A} \beta_{40}$ were assessed with the Amorfix $\mathrm{A} \beta$ immunoassay and the aggregated soluble and insoluble forms of $\mathrm{A} \beta$ were quantified using the Amorfix $\mathrm{A}^{4}$ assay. The $\mathrm{A}^{4}$ is a sensitive immunoassay that allows quantification of aggregated $\mathrm{A} \beta$ levels well before plaques can be detected by immunohistochemical means. The $\mathrm{A}^{4}$ matrix enriches for insoluble fibrils, as well as smaller soluble oligomers, up to and including trimeric $\mathrm{A} \beta$. Neither drug treatment altered cortical levels of aggregated or monomeric A $\beta$ (Figure $6 \mathrm{a}-\mathrm{c}$ ). Similar results were obtained with hippocampal tissue samples (data not shown). We also assessed cortical levels of holoAPP and $\beta-C$ terminal fragments $(\beta$-CTF) by western blot analysis with the monoclonal antibody, 6E10 (Figure 6d). 6E10 is directed toward amino-acid residues $1-16$ of $\mathrm{A} \beta$, which are within the 99-residue carboxy-terminal fragment of APP that is produced by $\beta$-secretase cleavage. $6 \mathrm{E} 10$ also reacts with full-length APP protein. Neither drug altered APP levels (not shown) nor $\beta$-CTF expression (Figure 6e).

\section{Dexefaroxan and Rivastigmine Increase BDNF mRNA}

We examined whether dexefaroxan and rivastigmine treatment might alter hippocampal BDNF mRNA levels, at two stages of plaque pathology (Figure 7). Treatments were initiated in 12-week-old TgCRND8 mice, at the onset of plaque deposition and in another cohort of 45- to 50 -weekold mice with advanced plaque pathology. Levels of $\beta$-actin mRNA were found to be equivalent in all mice, regardless of genotype or drug treatment $(P>0.05$, data not shown). Results were obtained as copies per $50 \mathrm{ng}$ total RNA and expressed as a ratio of $\mathrm{BDNF} / \beta$-actin mRNA. In the young mice, we found interacting effects of genotype and treatment on BDNF mRNA levels $\left(\mathrm{F}_{2,50}=3.85, P=0.0279\right)$. In 1-yearold mice, both genotype $\left(\mathrm{F}_{1,37}=32.54, P<0.0001\right)$ and treatment $\left(\mathrm{F}_{2,37}=3.24, P=0.05\right)$ were found to affect BDNF mRNA expression. BDNF mRNA was reduced in young $(t(9)=2.45, P=0.036)$ and aged $(t(13)=4.78, P=0.0004)$ TgCRND8 mice. Neither treatment altered BDNF expression in non-Tg mice. Both drugs increased BDNF expression in TgCRND8 mice. However, in young mice, the increase was significant only with rivastigmine treatment $(t(9)=3.63$, $P=0.005$; Figure $7 \mathrm{a}$ ). By 1 year of age, dexefaroxan significantly improved BDNF mRNA levels in TgCRND8 mice $(t(12)=2.24, P=0.044$; Figure $7 \mathrm{~b})$.

\section{DISCUSSION}

This study provides the first longitudinal analysis of TgCRND8 brain catecholamine content and reveals that noradrenergic deficits precede amyloid deposition in an APP-Tg mouse. These spontaneous reductions in tissue NA contribute to behavioral impairment and BDNF deficits.

TgCRND8 phenotypes are driven by the production and accumulation of $\mathrm{A} \beta$. How $\mathrm{A} \beta$ leads to neuronal dysfunction and behavioral abnormalities is unknown. We reported previously that TgCRND8 mice develop object memory deficits by 8 weeks of age, before frank plaque pathology but coincident with a twofold increase in $\mathrm{A} \beta$ levels and reduced BDNF mRNA in the hippocampus and frontal cortex (Francis et al, 2012). We argued that decreased BDNF expression contributes to the functional disruption of these brain regions that are first targeted by amyloid.

BDNF is synthesized in part by noradrenergic neurons (Marien et al, 2004) and has been found to promote the survival and phenotypic maturation of these neurons during development (Holm et al, 2003; Traver et al, 2006). $\mathrm{BDNF}$ is also required for the maintenance of noradrenergic innervation in the aging brain (Matsunaga et al, 2004). It is trophic for both catecholaminergic and cholinergic neurons, and is transported to and from the forebrain in noradrenergic neurons (reviewed in Marien et al, 2004 and Matsunaga et al, 2004).

In view of the trophic relationship between BDNF and noradrenergic neurons, we anticipated finding decreased NA content in TgCRND8 brains. We found such reductions in the hippocampus, temporoparietal and frontal cortices, 

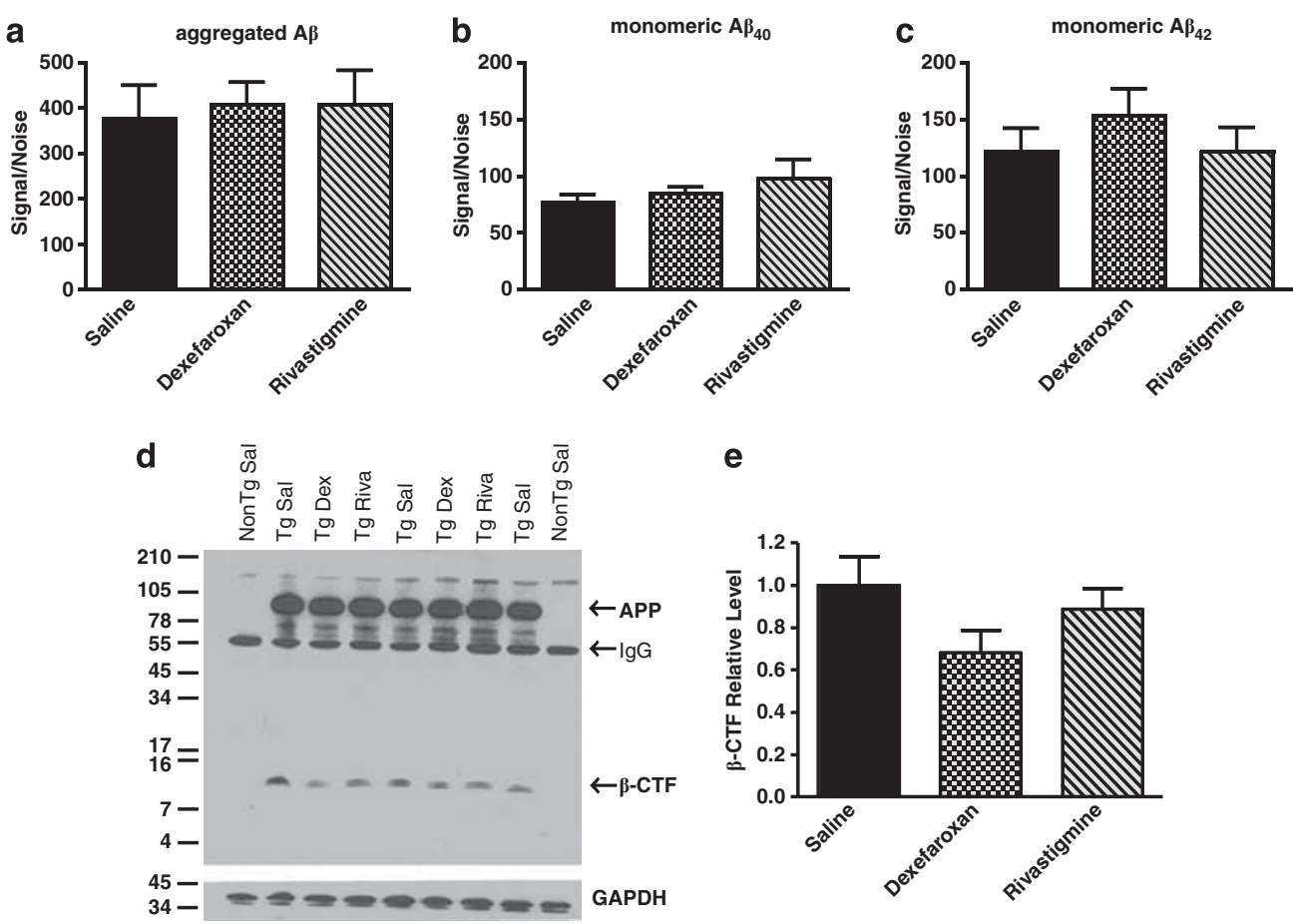

e

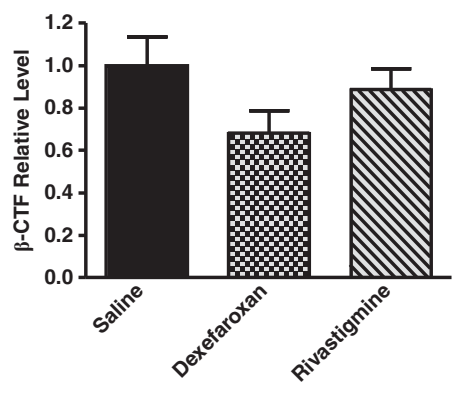

Figure 6 Dexefaroxan and rivastigmine do not affect $A \beta$, APP, or $\beta$-CTF levels. Top panels $(a-c)$ show that cortical levels of aggregated A $\beta$ (a), monomeric $A \beta_{40}$ (b), and monomeric $A \beta_{42}$ (c) in 16-week-old TgCRND8 mice were unaffected by dexefaroxan or rivastigmine treatment as measured by Amorfix immunoassays with time-resolved fluorescence. Results are mean values \pm SEM of seven mice per group. The signal/noise ratio was calculated by dividing the europium-fluorescent readout signal from the sample by the signal from the dilution buffer alone. Samples were scored as negative if the signal/ noise ratio was $<2$. All non-transgenic samples scored negative (not shown). (d) Representative immunoblot of cortical tissue homogenates from I6-weekold non-Tg saline $(n=6)$, TgCRND8 saline $(n=7)$, TgCRND8 dexefaroxan $(n=7)$, and TgCRND8 rivastigmine $(n=7)$ treated mice probed with the $A \beta_{1-16}$ monoclonal antibody 6EIO. Blots were stripped and reprobed with GAPDH-specific antibody to ensure equal loading of protein. (e) Densitometric analysis of $\beta$-CTF band intensities (normalized against GAPDH signal) was performed using Imagel software. Effect of treatments on band intensity is shown relative to the average staining intensity obtained for TgCRND8 saline samples (which was set to I). Neither drug altered levels of holoAPP (not shown) or $\beta$-CTF. Values are mean values $\pm \mathrm{SEM}$, obtained from three independent experiments.

and cerebellum of 4-week-old mice. Analyses of older TgCRND8 mice revealed reduced levels of NA in the cortex and progressive deficits in the hippocampus. In the cerebral cortex of aged non-Tg control mice, we found tissue content of NA to be elevated relative to younger mature animals. Similar age-dependent increases in cortical NA content have been reported in the rat (Harik and McCracken, 1986). While noradrenergic projections to the frontal cortex decrease with age, axonal branching and excitability of axon terminals of locus coeruleus neurons increase to maintain NA levels (Ishida et al, 2001). The higher degree of arborization and plasticity of the remaining noradrenergic axons in the frontal cortex may be mediated by BDNF (Matsunaga et al, 2004). Such compensatory increases in cortical NA levels appear to be absent in the aging TgCRND8 brain. The regional specificity of noradrenergic deficits suggests that cortical- and hippocampal-projecting cells in the locus coeruleus are damaged in TgCRND8 animals. In contrast, the ventral mesencephalon, striatum, and brainstem, all of which receive noradrenergic innervation from nuclei outside the locus coeruleus (Berridge and Waterhouse, 2003; Mejías-Aponte et al, 2009) are unaffected. This pattern of NA tissue deficits resembles what has been described in the human disease. In $\mathrm{AD}$, noradrenergic cell loss is attributed to retrograde degeneration of rostral, cortical-projecting cells of the locus coeruleus (Marcyniuk et al, 1986; German et al, 1992; Manaye et al, 1995).

Reductions in NA and BDNF constitute pathogenically significant steps in $\mathrm{A} \beta$-induced functional impairment and occur early in disease progression. In contrast, deleterious effects on cholinergic neurons and decreased cortical acetylcholine release have been reported in TgCRND8 animals at 7, but not 2 months of age (Bellucci et al, 2006). Thus, cholinergic dysfunction may follow the development of noradrenergic deficits in the TgCRND8 mouse. The degeneration of the locus coeruleus has been reported in mild cognitive impairment and is suggested to mediate the emergence of dementia in human $\mathrm{AD}$ (Grudzien et al, 2007). An early loss of tissue NA also appears to influence development of behavioral phenotypes in TgCRND8 mice. Eight-week-old TgCRND8 mice exhibited increased behavioral despair in the tail suspension test in addition to object memory impairment. The NA reuptake inhibitor desipramine reversed immobility, implicating noradrenergic deficits in the development of this depressive phenotype.

To test whether reduced noradrenergic tone in major terminal fields might have caused TgCRND8 behavioral dysfunction, we examined effects of enhancing noradrenergic transmission with dexefaroxan. Dexefaroxan blocks $\alpha_{2}$-adrenergic autoreceptors as well as inhibitory 
a
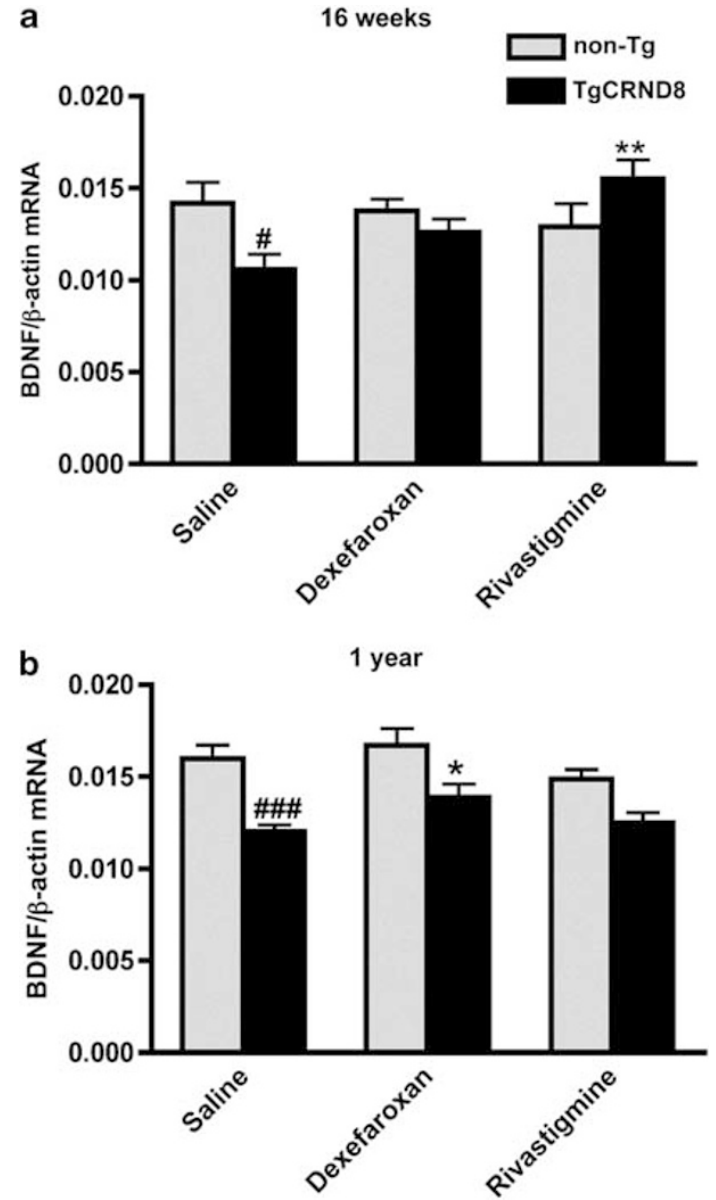

Figure 7 Dexefaroxan and rivastigmine rescue BDNF mRNA levels in TgCRND8 mice. BDNF mRNA levels were measured by absolute quantitative real-time reverse transcriptase polymerase chain reaction (qRT-PCR). (a) Reduced levels of BDNF mRNA in hippocampi of 16week-old TgCRND8 mice were restored with rivastigmine treatment. (b) In I-year-old TgCRND8 mice, dexefaroxan increased BDNF mRNA. Data are expressed as ratio of copies of BDNF mRNA/ $\beta$-actin mRNA. Values are mean values \pm SEM of $\geqslant 6$ mice per group. $* P \leqslant 0.05$, $* * P \leqslant 0.01$ vs

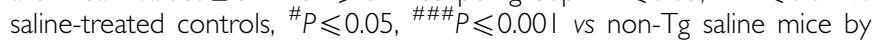
two-way ANOVA followed by Fisher's protected LSD test.

$\alpha_{2}$-adrenoceptors expressed heterologously on non-noradrenergic cells, including cholinergic neurons (reviewed in Chopin et al, 2002). Thus, dexefaroxan not only increases noradrenergic release (Rizk et al, 2006) but can also produce dose-dependent and sustained increase in cortical acetylcholine release (Tellez et al, 1999). Both dexefaroxan and rivastigmine ameliorated object memory deficits and behavioral despair of TgCRND8 animals. It is unlikely that our treatments improved behavior by eliciting a general stimulant-type, hyperkinetic effect, as neither drug influenced object exploration, or the immobility scores of non-Tg mice.

The behavioral phenotypes we observed could not be explained by frank motor differences. TgCRND8 and nonTg mice spent equal time exploring objects in the object memory test and no gross difference in motor activity was discerned. To test motor coordination more directly, we assessed a tape removal task that is sensitive to altered dopaminergic transmission in the striatum and substantia nigra (reviewed in Meredith and Kang, 2006; Schallert et al, 1982; Chen et al, 2005). We found TgCRND8 mice to be unimpaired in performing this task (Supplementary Figure S2). Moreover, we observed no differences between these mice and their non-Tg controls in tissue levels of DA and its metabolites within the striatum and ventral mesencephalon.

The apparent absence of dopaminergic dysfunction in our mice is consistent with the findings in human $\mathrm{AD}$ (reviewed in Hardy et al, 1985; Palmer et al, 1987a, b; Dringenberg, 2000), but at odds with previous results of Ambrée et al (2009), who reported elevated levels of DA in the frontal cortex and neostriatum of TgCRND8 mice, as well as improved memory and reduced stereotypy in response to treatment with levodopa. These authors measured DA in freshly dissected brains. However, the tissue levels of DA and its metabolites are strongly influenced by a postmortem surge in transmitter release and degradation. For this reason, we used rapid heat inactivation of tissue enzymes immediately before brain dissection. We found no differences in DA, or alteration in tissue levels of 3-MT, an indicator of released DA in the microwave-inactivated brain (Wood and Altar, 1988). As levodopa is a precursor of both DA and NA, we are left to speculate that it was increasing noradrenergic, rather than dopaminergic tone that led to reported effects of this drug on TgCRND8 behavior (Ambrée et al, 2009).

Rivastigmine can significantly improve mood in patients with mild-to-moderate AD (Finkel, 2004). However, it is now well appreciated that cholinergic deficits alone are insufficient to account for the various clinical manifestations of $\mathrm{AD}$ (Dringenberg, 2000). The loss of NA and its trophic effects on forebrain cholinergic activity can cause cognitive as well as depressive symptoms in $\mathrm{AD}$ (reviewed in Marien et al, 2004; Herrmann et al, 2004). In mice, dexefaroxan improves cognition (Chopin et al, 2002) and can prevent cholinergic atrophy (Debeir et al, 2002; Traver et al, 2005) following basal forebrain cholinergic damage. Dexefaroxan may alleviate behavioral despair, by enhancing both noradrenergic and cholinergic transmission. Acetylcholine can reciprocally stimulate noradrenergic neurons in the locus coeruleus (Engberg and Svensson, 1980; Strong et al, 1991). The possibility that cholinergic as well as noradrenergic mechanisms contribute to affective phenotypes is supported by the observation that both rivastigmine and dexefaroxan were active in reducing behavioral despair.

Progressive damage to noradrenergic terminals and the locus coeruleus has been described in multiple APP-Tg models (reviewed in Kalinin et al, 2011). In all of these mice, degenerative changes in the locus coeruleus were observed well after the onset of plaque deposition. In contrast, we now report that TgCRND8 mice exhibit reduced terminal concentrations of NA weeks before behavioral dysfunction and plaque deposition.

We assessed the effects of chronic treatment with either dexefaroxan or rivastigmine on hippocampal levels of NA and normetanephrine, its extracellular metabolite (Supplementary Figure S3). Dexefaroxan reduced NA, but marginally increased normetanephrine in non-Tg mice. This is consistent with a presynaptic action of the drug on intact noradrenergic terminals, as ex vivo tissue normetanephrine levels directly reflect NA turnover in microwaveinactivated brain (Wood et al, 1987). In contrast, untreated 
TgCRND8 mice exhibited decreased tissue NA and increased normetanephrine, suggesting a compensatory increase in transmitter release from intact noradrenergic terminals. Both dexefaroxan and rivastigmine normalized TgCRND8 normetanephrine levels, without changing tissue levels of NA. These observations suggest a loss of terminals and reduced reuptake of released transmitter, as has been described in clinical populations by Palmer et al (1987b). Elevated turnover and increased firing of surviving noradrenergic neurons have also been described in $\mathrm{AD}$ patients (Palmer et al, 1987b; Szot et al, 2006).

Neither dexefaroxan nor rivastigmine reduced the monomeric or aggregated $\mathrm{A} \beta$ burden in TgCRND8 brains. Similarly, neither drug significantly affected APP or $\beta$-CTF expression. In contrast, APP-Tg mice treated with the neurotoxin DSP-4 were found to exhibit a fivefold increase in plaque burden and decreased expression and activity of an $\mathrm{A} \beta$ degrading protease, neprilysin (Kalinin et al, 2007). This increased amyloid load was associated with inflammation and impaired microglial phagocytosis of $\mathrm{A} \beta$. Replenishing NA in DSP-4-treated mice restored microglial migration and $\mathrm{A} \beta$ phagocytosis (Heneka et al, 2010). While loss of noradrenergic innervation can promote amyloid deposition, treating with an $\alpha_{2}$-adrenoceptor antagonist may not affect $\mathrm{A} \beta$ levels in the brain. The therapeutic actions of our drugs are likely independent of the effects on $\mathrm{A} \beta$ accumulation. By 16 weeks, $\mathrm{A} \beta$ plaques are abundant in the hippocampus and cortex, although we found cytokine expression to remain unchanged (Ma et al, 2011). Only at late stages of amyloid pathology have we found IL- $1 \beta$ to be upregulated in the TgCRND8 brain. It is possible that by 28 weeks, a time point at which microglial activation is observed in this model, an effect of desipramine on neuroinflammatory measures might be discerned.

We reported previously that downregulation of $\mathrm{BDNF}$ mRNA can be induced by large oligomer formations of $\mathrm{A} \beta$ and high $\mathrm{A} \beta_{42} / \mathrm{A} \beta_{40}$ ratios (Peng et al, 2009). These conditions are achieved before the onset of plaque pathology in TgCRND8 mice and decreased BDNF mRNA is observed in mice only 6-8 weeks of age (Francis et al, 2012). BDNF has established roles in synaptic plasticity, mood, and memory (reviewed by Coyle and Duman, 2003). NA can induce the production of BDNF and mitigate $\mathrm{A} \beta$ induced stress through stimulation of canonical $\beta$-adrenoceptor cAMP pathways (Counts and Mufson, 2010). By corollary, reduction in tissue $\mathrm{NA}$ may exacerbate $\mathrm{A} \beta$ induced BDNF deficits.

Dexefaroxan increases BDNF expression in afferent noradrenergic fibers and in hippocampal granule cells (Rizk et al, 2006). Cholinomimetic drugs also induce BDNF expression in the brain (Srivareerat et al, 2011) and can elevate serum BDNF concentrations of $\mathrm{AD}$ patients to levels found in healthy controls (Leyhe et al, 2008). In TgCRND8 mice, both dexefaroxan and rivastigmine upregulated hippocampal BDNF mRNA. This effect of dexefaroxan persisted even at advanced stages of amyloid accumulation.

In sum, early depletion of NA within selected terminal fields constitutes a pathophysiologically relevant event in this robust mouse model of $\mathrm{A} \beta$ deposition. Dexefaroxan and rivastigmine ameliorated memory impairment and behavioral despair in addition to increasing BDNF mRNA. Our results suggest that increasing noradrenergic transmission may warrant consideration as part of a therapeutic strategy in the treatment of $\mathrm{AD}$.

\section{ACKNOWLEDGEMENTS}

We thank Dr Marc Marien (Centre de Recherche Pierre Fabre) for the generous gift of dexefaroxan hydrochloride and Ms Virginie Nguyen for guidance in the microwaved brain dissection.

\section{DISCLOSURE}

The authors declare that this work was funded by the Ontario Mental Health Foundation (to HM), Canadian Institutes of Health Research (PRG-37857: to JM), an Ontario Graduate Scholarship (to BF) and the KM Hunter Ontario Student Opportunity Trust Fund award (to BF). Over the past 3 years, JM has received compensation from Elan Pharmaceuticals for work not relevant to this study.

\section{REFERENCES}

Adolfsson R, Gottfries CG, Roos BE, Winblad B (1979). Changes in the brain catecholamines in patients with dementia of Alzheimer type. Br J Psychiatry 135: 216-223.

Ambree O, Richter H, Sachser N, Lewejohann L, Dere E, de Souza Silva MA et al (2009). Levodopa ameliorates learning and memory deficits in a murine model of Alzheimer's disease. Neurobiol Aging 30: 1191-1204.

Barfield ET, Barry SM, Hodgin HB, Thompson BM, Allen SS, Grisel JE (2010). $\beta$-endorphin mediates behavioral despair and the effect of ethanol on the tail suspension test in mice. Alcohol Clin Exp Res 34: 1066-1072.

Bellucci A, Luccarini I, Scali C, Prosperi C, Garzia M, Giovannini MG et al (2006). Cholinergic dysfunction, neuronal damage and axonal loss in TgCRND8 mice. Neurobiol Dis 23: 260-272.

Berridge CW, Waterhouse BD (2003). The locus coeruleusnoradrenergic system: modulation of behavioral state and state-dependent cognitive processes. Brain Res Rev 42: 33-84.

Bondareff W, Mountjoy CQ, Roth M (1982). Loss of neurons of origin of the adrenergic projection to cerebral cortex (nucleus locus coeruleus) in senile dementia. Neurology 32: 164-168.

Bondareff W, Mountjoy CQ, Roth M, Rossor MN, Iversen LL, Reynolds GP et al (1987). Neuronal degeneration in locus coeruleus and cortical correlates of Alzheimer's disease. Alzheimer Dis Assoc Discord 1: 256-262.

Braak H, Braak E (1991). Neuropathological staging of Alzheimerrelated changes. Acta Neuropathol (Berl) 82: 239-259.

Braak H, Del Tredici K (2004). Alzheimer's disease: intraneuronal alterations precede insoluble amyloid- $\beta$ formation. Neurobiol Aging 25: 713-718.

Chen L, Cagniard B, Mathews T, Jones S, Koh HC, Ding Y et al (2005). Age-dependent motor deficits and dopaminergic dysfunction in DJ-1 null mice. J Biol Chem 280: 21418-21426.

Chishti MA, Yang D, Janus C, Phinney A, Horne P, Pearson J et al (2001). Early-onset amyloid deposition and cognitive deficits in transgenic mice expressing a double mutant form of amyloid precursor protein 695. J Biol Chem 276: 21562-21570.

Chopin P, Colpaert FC, Marien M (2002). Effects of acute and subchronic administration of dexefaroxan, an $\alpha_{2}$-adrenoceptor antagonist, on memory performance in young adult and aged rodents. J Pharmacol Exp Ther 301: 187-196.

Counts S, Mufson E (2010). Noradrenaline activation of neurotrophic pathways protects against neuronal amyloid toxicity. J Neurochem 113: 649-660. 
Coyle JT, Duman RS (2003). Finding the intracellular signaling pathways affected by mood disorder treatments. Neuron 38: 57-160. Coyle JT, Price DL, DeLong MR (1983). Alzheimer's disease: a disorder of cortical cholinergic innervation. Science 219: 1184-1190.

Cryan JF, Mombereau C, Vassout A (2005). The tail suspension test as a model for assessing antidepressant activity: review of pharmacological and genetic studies in mice. Neurosci Biobehav Rev 29: 571-625.

Davies P, Maloney AJ (1976). Selective loss of central cholinergic neurons in Alzheimer's disease. Lancet 2: 1403.

Debeir T, Marien M, Chopin P, Martel J-C, Colpaert F, RaismanVozari R (2002). Protective effects of the $\alpha_{2}$-adrenoceptor antagonist, dexefaroxan, against degeneration of the basalocortical cholinergic system induced by cortical devascularization in the adult rat. Neuroscience 115: 41-53.

DeToledo-Morrell L, Sullivan MP, Morrell F, Wilson RS, Bennett DA, Spencer S (1997). Alzheimer's disease: in vivo detection of differential vulnerability of brain regions. Neurobiol Aging 18: 463-468.

Dringenberg HC (2000). Alzheimer's disease: more than a 'cholinergic disorder'-evidence that cholinergic-monoaminergic interactions contribute to EEG slowing and dementia. Behav Brain Res 115: 235-249.

Engberg G, Svensson TH (1980). Pharmacological analysis of a cholinergic receptor mediated regulation of brain norepinephrine neurons. J Neural Transm 49: 137-150.

Finkel SI (2004). Effects of rivastigmine on behavioral and psychological symptoms of dementia in Alzheimer's disease. Clin Ther 26: 980-990.

Foote SL, Bloom FE, Aston-Jones G (1983). Nucleus locus coeruleus: new evidence of anatomical and physiological specificity. Physiol Rev 63: 844-914.

Forno LS (1966). Pathology of Parkinsonism. J Neurosurg 24: 266-271.

Francis BM, Kim J, Barakat ME, Fraenkl S, Yucel YH, Peng S et al (2012). Object recognition memory and BDNF expression are reduced in young TgCRND8 mice. Neurobiol Aging 33: 555-563.

Francis PT, Palmer AM, Snape M, Wilcock GK (1999). The cholinergic hypothesis of Alzheimer's disease: a review of progress. J Neurol Neurosurg Pyschiatry 66: 137-147.

Galeotti N, Ghelardini C (2011). Regionally selective activation and differential regulation of ERK, JNK and p38 MAP kinase signaling pathway by protein kinase $\mathrm{C}$ in mood modulation. Int J Neuropsychopharmacol; e-pub ahead of print 20 June 2011.

German DC, Manaye KF, White III CL, Woodward DJ, McIntire DD, Smith WK et al (1992). Disease-specific patterns of locus coeruleus cell loss. Ann Neurol 32: 667-676.

Gonzalo-Ruiz A, Gonzalez I, Sanz-Anquela JM (2003). Effects of $\beta$ amyloid protein on serotonergic, noradrenergic, and cholinergic markers in neurons of the pontomesencephalic tegmentum in the rat. J Chem Neuroanat 26: 153-169.

Grudzien A, Shaw P, Weintraub S, Bigio E, Mash DC, Mesulam MM (2007). Locus coeruleus neurofibrillary degeneration in aging, mild cognitive impairment and early Alzheimer's disease. Neurobiol Aging 28: 327-335.

Hardy J, Adolfsson R, Alafuzoff I, Bucht G, Marcusson J, Nyberg P et al (1985). Transmitter deficits in Alzheimer's disease. Neurochem Int 7: 545-563.

Harik SI, McCracken KA (1986). Age-related increase in presynaptic noradrenergic markers of the rat cerebral cortex. Brain Res 381: 125-130.

Heneka MT, Nadrigny F, Regen T, Martinez-Hernandez A, Dumitrescu-Ozimek L, Terwel D et al (2010). Locus coeruleus controls $\mathrm{AD}$ pathology by modulating microglial functions through norepinephrine. PNAS 107: 6058-6063.

Heneka MT, Ramanathan M, Jacobs AH, Dumitrescu-Ozimek L, Bilkei-Gorzo A, Debeir T (2006). Locus coeruleus degeneration promotes Alzheimer pathogenesis in amyloid precursor protein 23 transgenic mice. J Neurosci 26: 1343-1354.

Herrmann N, Lanctot KL, Khan LR (2004). The role of norepinephrine in the behavioral and psychological symptoms of dementia. J Neuropsychiatry Clin Neurosci 16: 261-276.

Holm PC, Rodriguez FJ, Kresse A, Canals JM, Silos-Santiago I, Arenas E (2003). Crucial role of TrkB ligands in the survival and phenotypic differentiation of developing locus coeruleus noradrenergic neurons. Development 130: 3535-3545.

Ishida Y, Shirokawa T, Komatsu Y, Isobe K (2001). Changes in cortical noradrenergic axon terminals of locus coeruleus neurons in aged F344 rats. Neurosci Lett 307: 197-199.

Janus C, Pearson J, McLaurin J, Mathews PM, Jiang Y, Schmidt SD et al (2000). A $\beta$ peptide immunization reduces behavioral impairment and plaques in a model of Alzheimer's disease. Nature 408: 979-982.

Jardanhazi-Kurutz D, Kummer MP, Terwel D, Vogel K, Dyrks T, Thiele A et al (2010). Induced LC degeneration in APP/PS1 transgenic mice accelerates early cerebral amyloidosis and cognitive deficits. Neurochem Int 57: 375-382.

Jardanhazi-Kurutz D, Kummer MP, Terwel D, Vogel K, Thiele A, Heneka MT (2011). Distinct adrenergic system changes and neuroinflammation in response to induced locus coeruleus degeneration in APP/PS1 transgenic mice. Neuroscience 176: 396-407.

Kalinin S, Gavrilyuk V, Polak PE, Vasser R, Zhao J, Heneka MT et al (2007). Noradrenaline deficiency in brain increases betaamyloid plaque burden in an animal model of Alzheimer's disease. Neurobiol Aging 28: 1206-1214.

Kalinin S, Polak PE, Lin SX, Sakharkar AJ, Pandey SC, Feistein DL (2011). The noradrenaline precursor L-DOPS reduces pathology in a mouse model of Alzheimer's disease. Neurobiol Aging; e-pub ahead of print 24 June 2011.

Leyhe T, Stransky E, Eschweiler GW, Buchkremer G, Laske C (2008). Increase of BDNF serum concentration during donepezil treatment of patients with early Alzheimer's disease. Eur Arch Psychiatry Clin Neurosci 258: 124-128.

Ma K, Mount HTJ, McLaurin J (2011). Region-specific distribution of $\beta$-amyloid peptide and cytokine expression in TgCRND8 mice. Neurosci Lett 492: 5-10.

Manaye KF, McIntire DD, Mann DM, German DC (1995). Locus coeruleus cell loss in the aging human brain: a non-random process. J Comp Neurol 358: 79-87.

Mann DMA, Yates PO, Hawkes J (1982). The noradrenergic system in Alzheimer's and multi-infarct dementias. J Neurol Neurosurg Psychiatry 45: 113-119.

Marcyniuk B, Mann DMA, Yates PO (1986). The topography of cell loss from locus coeruleus in Alzheimer's disease. J Neurol Sci 76: 335-345.

Marien MR, Colpaert FC, Rosenquist AC (2004). Noradrenergic mechanisms in neurodegenerative diseases: a theory. Brain Res Rev 45: 38-78.

Matsunaga W, Shirokawa T, Isobe K (2004). BDNF is necessary for maintenance of noradrenergic innervations in the aged rat brain. Neurobiol Aging 25: 341-348.

Matthews KL, Chen CP, Esiri MM, Keene J, Minger SL, Francis PT (2002). Noradrenergic changes, aggressive behaviour and cognition in patients with dementia. Biol Psychiatry 51: 407-416.

Mejías-Aponte CA, Drouin C, Aston-Jones G (2009). Adrenergic and noradrenergic innervation of the midbrain ventral tegmental area and retrorubral field: prominent inputs from medullary homeostatic centres. Neuroscience 29: 3613-3626.

Meredith GE, Kang UJ (2006). Behavioral models of Parkinson's disease in rodents: a new look at an old problem. Mov Disord 21: 1595-1606.

Moroji T, Takahashi K, Ikeda C (1978). Levels of biogenic amines and their metabolites in rat whole brain after rapid tissue fixation with microwave irradiation. No To Skinkei 30: 1303-1308. 
Mount HTJ, Martel J-C, Fluit P, Wu Y, Gallo-Hendrikx E, Cosi C et al (2004). Progressive sensorimotor impairment is not associated with reduced dopamine and high energy phosphate donors in a model of ataxia-telangiectasia. J Neurochem 88: 1449-1454.

Ohno M, Yoshimatsu A, Kobayashi M, Watanabe S (1997). Noradrenergic DSP-4 lesions aggravate impairment of working memory produced by hippocampal muscarinic blockade in rats. Pharmacol Biochem Behav 57: 257-261.

Palmer AM, Francis PT, Bowen DM, Benton JS, Neary D, Mann DM et al (1987b). Catecholaminergic neurones assessed ante-mortem in Alzheimer's disease. Brain Res 414: 365-375.

Palmer AM, Wilcock GK, Esiri MM, Francis PT, Bowen DM (1987a). Monoaminergic innervations of the frontal and temporal lobes in Alzheimer's disease. Brain Res 401: 231-238.

Peng S, Garzon DJ, Marchese M, Klein W, Ginsberg SD, Francis $\mathrm{BM}$ et al (2009). Decreased brain-derived neurotrophic factor depends on amyloid aggregation state in transgenic mouse models of Alzheimer's disease. J Neurosci 29: 9321-9329.

Rizk P, Salazar J, Raisman-Vozari R, Marien M, Ruberg M, Colpaert $\mathrm{F}$ et al (2006). The alpha2-adrenoceptor antagonist dexefaroxan enhances hippocampal neurogenesis by increasing the survival and differentiation of new granule cells. Neuropsychopharmacology 31: 1146-1157.

Schallert T, Upchurch M, Lobaugh N, Farrar SB, Spirduso WW, Gilliam P et al (1982). Tactile extinction: distinguishing between sensorimotor and motor asymmetries in rats with unilateral nigrostriatal damage. Pharmacol Biochem Behav 16: 455-462.

Srivareerat M, Tran TT, Salim S, Aleisa AM, Alkadhi KA (2011). Chronic nicotine restores normal $\mathrm{A} \beta$ levels and prevents shortterm memory and E-LTP impairment in $\mathrm{A} \beta$ rat model of Alzheimer's disease. Neurobiol Aging 32: 834-844.

Steru L, Chermat R, Thierry B, Simon P (1985). The tail suspension test: a new method for screening antidepressants in mice. Psychopharmacology 85: 367-370.

Stoub TR, Rogalski EJ, Leurgans S, Bennett DA, DeToledo-Morrell L (2010). Rate of entorhinal and hippocampal atrophy in incipient and mild AD: relation to memory function. Neurobiol Aging 31: 1089-1098.

Strong R, Huang JS, Huang SS, Chung HD, Hale C, Burke WJ (1991). Degeneration of the cholinergic innervation of the locus coeruleus in Alzheimer's disease. Brain Res 542: 23-28.

Szot P, White SS, Greenup JL, Leverenz JB, Peskind ER, Raskind MA (2006). Compensatory changes in the noradrenergic nervous system in the locus ceruleus and hippocampus of postmortem subjects with Alzheimer's disease and dementia with lewy bodies. J Neurosci 26: 467-478.
Tanghe A, Termont A, Merchiers P, Schilling S, Demuth H, Scrocchi L et al (2010). Pathological Hallmarks, clinical parallels, and value for drug testing in Alzheimer's disease of the APP[V717I] London transgenic mouse model. Int J Alzheimer Dis; e-pub ahead of print 2 September 2010.

Tellez S, Colpaert F, Marien M (1999). $\alpha_{2}$-Adrenoceptor modulation of cortical acetylcholine release in vivo. Neuroscience 89: 1041-1050.

Thal DR, Rub U, Schultz C, Sassin I, Ghebremedhin E, Del Tredici K et al (2000). Sequence of abeta-protein deposition in the human medial temporal lobe. J Neuropathol Exp Neurol 59: 733-748.

Thal DR, Rub U, Orantes M, Braak H (2002). Phases of a betadeposition in the human brain and its relevance for the development of AD. Neurology 58: 1791-1800.

Traver S, Marien M, Martin E, Hirsch EC, Michel PP (2006). The phenotypic differentiation of locus coeruleus noradrenergic neurons mediated by brain-derived neurotrophic factor is enhanced by corticotropin releasing factor through the activation of a cAMP-dependent signaling pathway. Mol Pharmacol 70: 30-40.

Traver S, Salthun-Lassalle B, Marien M, Hirsch EC, Colpaert F, Michel PP (2005). The neurotransmitter noradrenaline rescues septal cholinergic neurons in culture from degeneration caused by low-level oxidative stress. Mol Pharmacol 67: 1882-1891.

Van Dam D, Abramowski D, Staufenbiel M, De Deyn PP (2005). Symptomatic effect of donepezil, rivastigmine, galantamine and memantine on cognitive deficits in the APP23 model. Psychopharmacology 180: 177-190.

Veyrac A, Didier A, Colpaert F, Jourdan F, Marien M (2005). Activation of noradrenergic transmission by $\alpha_{2}$-adrenoceptor antagonists counteract deafferentation-induced neuronal death and cell proliferation in the adult mouse olfactory bulb. Exp Neurol 194: 444-456.

Wood PL, Altar CA (1988). Dopamine release in vivo from nigrostriatal, mesolimbic and mesocortical neurons: utility of 3-methoxytyramine measurements. Pharmacol Rev 40: $163-187$.

Wood PL, Kim HS, Altar CA (1987). In Vivo assessment of dopamine and noradrenaline release in rat neocortex: gas chromatography-mass spectrometry measurement of 3-Methoxytyramine and normetanephrine. J Neurochem 48: 574-579.

Zarow C, Lyness SA, Mortimer JA, Chui HC (2003). Neuronal loss is greater in the locus coeruleus than nucleus basalis and substantia nigra in Alzheimer and Parkinson diseases. Arch Neurology 60: 337-341.

Supplementary Information accompanies the paper on the Neuropsychopharmacology website (http://www.nature.com/npp) 